\title{
ÚJ KÖNYVSOROZAT ANGOLUL: REGIONAL RESEARCH REPORTS
}

Érthető, hogy minden kis nemzetet szüntelenül foglalkoztat a kérdés, jelen van-e a „világ köztudatában", mennyire figyelnek oda rá. Különösen fontos a nemzetközi kapcsolatok tudatos ápolása az olyan népek számára, amelyek nyelve nem hasonlít egyetlen világnyelvre sem. A tudományos életben az egészséges vérkeringés fenntartása megköveteli a legújabb külföldi kutatási eredmények gyors befogadását és a hazaiak mielőbbi közzétételét. Lengyelországban az oktatás színvonala, a kutatók nagy száma és szakosodása, a világjárás, nyelvtudás stb. mellett lamelyek kétségtelenül az elsődleges tényezők), az is növelte a regionális tudományok hírnevét, hogy már a hatvanas évek elejétöl több sorozat szakosodott az e téren elért eredmények angol vagy francia nyelvű közlésére (például a Geographia Polonica vagy a Lengyel Tudományos Akadémia Területi Gazdaságtan és Regionális Tervezés Bizottságának kiadványai: Bulletin, Études stb.). Ez lehetővé teszi a ,belföldi" gondolatok közvetett szembesülését a tudomány legjelesebb képviselőivel, megfelelő mércét adva ezzel az eredmények értékeléséhez, hozzásegítve a további kutatási irányok helyes rangsorolásához.

Ezt a célt kívánja szolgálni hazánkban a Regional Research Reports, a regionális, valamint a város- és falukutatás jelentős társadalomtudományi eredményeinek legújabb angol/amerikai nyelvü fóruma. A sorozat jellegét és témakörét tekintve nemzetközi és tudományközi kíván lenni. Nagy figyelmet fordit arra, hogy mindaddig fordításban nem hozzáférhető eredeti kutatási eredményeket tegyen közzé, olyanokat is, amelyek más, kevésbé ismert nyelven születtek. Jelentős teret szentel a nemzetközi tudományos együttmüködés keretében végzett összehasonlító tanulmányoknak, s örömmel fogadja a különböző kultúrákat vagy iskolákat képviselő szerző- illetve szerkesztőpárosok jelentkezését.

A Regional Research Reports tanulmánykötetekből, szöveggyújteményekból és monográfiákból álló sorozat, évente egy·két alkalommal jelenik meg. Az általános tudományos célkitǔzések mellett gyakorlati megfontolások is vezették a Regionális Kutatások Központját abban, hogy 1986-ban belefogjon ebbe a válialkozásba. Olyan, megjelenésében is színvonalas, „igazi könyvet" kívánt az asztalra letenni, amely megállja a helyét a szakkönyvek világpiacán, vonzó cserealap a csak dollárért beszerezhető kiadványokért, vagy illő ajándék a nemzetközi kapcsolatokban. A szerkesztőség nagy gondot fordít a kéziratok ábra-, térkép- és képanyagának színvonalas elókészitésére. A nyelvhelyességet szakmabeli anyanyelvi lektor ellenörzi.

A Regional Research Reports elsö kötete ENYEDI GY. - VELDMAN, J. (szerkesztők): Rural Development Issues in Industrialized Countries. A falufejlesztés kérdései ipari országokban.) 1000 példányban látott napvilágot. $A$ kötetbe válogatott tanulmányok (az 1983. novemberében megtartott holland-magyar földrajzi szeminárium angol nyelvű anyaga) a falusi térségek átalakulási problémáit és kilátásait tárják fel, illetve az ezzel kapcsolatos fejlesztési politikákat - mint például a központi falu 
fejlesztésének koncepciója - tárgyalják. A könyv átfogó képet nyújt Hollandia és Magyarország falusi térségeiröl, ahol - minden különbségük ellenére - a döntéshozóknak hasonló nehézségekkel kell megküzdeniök.

A szerkesztők közös bevezető tanulmánya a falusi településhálózat kutatásában és tervezésében jelentkező kulcskérdéseket tekinti át. Érvelnek az agrárföldrajzból szükségszerüen kinőtt faluföldrajz (rural geography) létjogosultsága mellett, amelynek témaköre felölei a megközelítés, a megközelíthetőség, a vándorlás, a falusi lakásépítés, a munkához jutás, az agráripari - kereskedelmi komplexum (agribusiness) a falusi üdülés, infrastruktúra és szolgáltatás, a településfejlesztés kérdéseit. A szerzők hangsúlyozzák, hogy a falvak fejlódését és változását nem lehet kizárólag az urbanizációnak tulajdonítani, vannak a falusi térségeknek sajátos belső erőforrásai is. A változásokat előidéző okok eredete (mezőgazdasági vagy nem mezőgazdasági, régón belüli vagy régión kívüli) szerint különbséget tesznek periferiális és városkörnyéki falusi térségek között. E két régiótípus szinte minden tekintetben különbözik (telekpiac, tömegközlekedés, szolgáltatások, helyi közösségek), s e különbségek középpontjában a termelési környezet és a munkaeröpiac áll.

A másik fontos különbségtétel a falusi térségek problémáinak megközelítési módjában van. Az absztrakció mértéke vagy a földrajzi lépték mérete szerint a periferiális és a városkörnyéki falusi térségeket is három szinten tárgyalják: országos, regionális és helyi szinten. Hangsúlyozzák többek között, hogy a falusi településhálózat gondjai a városkörnyéken országos programokkal (infrastruktúrahálózat, környezetvédelem, tömegek befogadására alkalmas zöldövezet) oldható meg, míg a perifériában a változások helyi megközelítést igényelnek, az ellátás kérdése sokkal élesebben vetődik fel. A falusi térségek osztályozásával kapcsolatban figyelemre méltó az a megállapítás, hogy Magyarországon továbbra is a falu - város kettősség a meghatározó. Kialakult ugyan a falusi - városkörnyéki - városi kontinuum, de kevés helyen és kis mértékben. A két holland és a hat magyar tanulmány általában színvonalas, jellegük és mélységük azonban különbözö. Ez nem nagy baj, legfeljebb meglepi az olvasót. Tömör állásfoglalás (LACKÓ LÁSZLÓ) pontokba fogott tény (SÁRFALVI BÉLA) váltakozik széleskörü empirikus elemzés eredményeit és számottevỏ elméleti munkát tartalmazó írásokkal. $\mathrm{Az}$ országos szintet három tanulmány képviseli: a holland városi és falusi területek demográfiai gazdasági helyzetének változásáról (MARC DE SMIDT); a falufejlesztés településhálózatfejlesztési politikán belül betöltött szerepérỏl (LACKÓ LÁSZLÓ) és a falusi iparról (BARTA GYÖRGYI).

A városkörnyéki falusi térségekről írottak nagy része érthetöen holland szerzőktöl származik: ALZEMA és DIJKSTRA a holland településfejlesztési politika három országos dokumentumában (Urbanization Report, Report on Rural Areas, Orientation Report) foglaltak hatását és hatékonyságát vizsgálja. Ezek a hetvenes évek második felében születtek. A szerzők szerint nemcsak azt kell vizsgálni, milyen mértékben teljesültek a célok, hanem azt is, hogy az alkalmazott eszközök egyáltalában (elméletileg) alkalmasak lehetnek-e a célok elérésének elősegítésére.

VAN GINKEL a Randstad (Hollandia városgyürüje) zöld szivének népességnövekedését és településszerkezetét vizsgálja. Ezzzel kapcsolatban maxurbanizációról, ruralizációról, rurbanizációról és szuburbanizációról beszél, ez utóbbi lehet „igazi”, 
„szétszórt", „rejtett”, „tervezett”, „valós”, és „lakóhelyi”. Megkülönböztet rurban maradókat és városkörnyéki (suburban) vándorlókat.

DOSTÁL és MARKUSSE egy harmadik szempontból, a helyi szolgáltatásokkal való ellátottság szempontjából vizsgálja a városkörnyéki falusi térségek változását. DOSTÁL és MARKUSSE Alkmaar térségének példáján végez mélyreható helyzetfeltárást, és mutatja be a különbözó megoldási módok elónyeit - hátrányait. A vizsgálat kiterjed nemcsak a népességszám változására, hanem - nagyon indokoltan - társadalmi tagozódására, jövedelmi viszonyaira is, amelyek természetesen szintén jelentősen befolyásolják az igényeket. Így tehát a mennyiségi és a minőségi viszonyokat egyaránt átfogó elemzést kapunk, ami különösen értékes. Figyelemre méltó a szolgáltatások öt és a települések szintén öt hierarchikus szintbe sorolása és a szintek 1972-1982 közötti vál tozása (88-89. oldal).

A magyar városkörnyéket SÁRFALVI BÉLA vizsgálata képviseli, amely a munkahely és a lakóhely területi kapcsolatának alakulását tekinti át a budapesti agglomerációban. Három egészoldalas térképe közül izgalmas az ingázás intenzitásának változását ér zékeltetô ábra (50. oldal). Az 1960-1980 alatti vándorlások egyenlege azonban több okból nem szerencsés választás térképi megjelenítésre: egyrészt a húsz év folyamán szélsőséges, de egymás hatását közömbösítő változások történhettek, másrészt - mint a 61 . oldalon látható - a vándorlási egyenleg csak a durva különbségtételre alkalmas.

A periferikus falusi térségekről szóló igen jól dokumentált tanulmányok sorát CSATÁRI BÁLINT - ENYEDI GYÖRGY dolgozata vezeti be. A falusi elnéptelenedés és hanyatlás hosszú évtizedei után bizonyos térségekben új dinamizmusnak lehetünk tanúi. Ez is bizonyítja, hogy a falvak nemcsak a városoktól, hanem belülről is nyerhetnek erőt a megújulásra. A szerzők Bács-Kiskun megyei esettanulmányukban azt feszegetik, hogy: a) milyen körülmények között jöttek itt létre új falvak; vajon ideiglenesek vagy tartósak lesznek-e a 200-300 telket számláló települések? b) Miféle ember ek laknak itt, életkorukat, nemüket, szakmájukat és képzettségüket tekintve, honnan jöttek, hol dolgoznak? c) Elégedettek-e az itt lakók körülményeikkel; milyen fejlett az infrastruktúra és az alapellátás?

A periferikus falusi térségekkel foglalkozik TÓTH JÓZSEF közép-békési és KÁRPÁTI ZOLTÁN Baranya megyei esettanulmányában. Utóbbi nemcsak a földrajzi, hanem a társadalmi perifériák területi összefüggéseit is fölveti. Mint a bevezető tanulmány is hangsúlyozza, a periferikus falusi térségek legnagyobb gondja az ellátás megszervezése. A közép- és felsőfokú ellátás helyben nem lehetséges (Hollandiában sem), a legfőbb feladat tehát az odajutás. HUIGEN egy hozzáférhetőség szimuláló programot mutat be, amelynek érdekessége a tér-idó megközelítés az egyének szempontjából. A program a nap 24 órájának, a nyitvatartási időknek, a közlekedési eszközök adta lehetőségeknek, a munkaidőnek, az iskolakezdés - befejezés időpontjának stb. az összehangolását végzi úgy, hogy minél több tevékenység minél kevesebb nem otthon eltöltött idó alatt elvégezhető legyen.

A Regionális Kutatások Központja a megjelent kötetek többségét exportra szánja. A hazai érdeklődők elsősorban a sorozat előjegyzésével gondoskodhatnak az egyes példányok beszerzéséről. A sorozat kötetei korlátozott számban kerülnek egy-két idegennyelvủ könyvesboltba. 
A sorozatot a regionális kutatás és tervezés valamennyi elméleti és gyakorlati szakemberének ajánljuk; haszonnal forgathatják a földrajzosok, a közgazdászok, a demográfusok, a szociológusok, a történészek és a néprajzosok. Az első kötet holland és magyar falufejlesztéssel foglalkozó szakemberek munkája, a második amerikai (Egyesült Államok) és magyar regionális tudósok irásait tartalmazza a területi folyamatok és a regionális politika legújabb eredményeiról.

KRÓNIKA

\section{KGST EGYÜTTMÚKÖDÉS \\ A KÖRNYEZETVÉDELEM TÁRSADALOMTUDOMÁNYI KUTATÁSAIBAN}

A KGST keretében összehangolt környezetvédelmi kutatások az alapkutatástól a mủszaki fejlesztési kutatásokig igen széles skálát fognak át. Időben ez az együttmüködés a KGST Tudományos-Müszaki Együttmüködési Bizottság irányítása alatt 1973-ig nyúlik vissza. Az átfogó program keretében 1981-85 között már 14 nagy problémakört kutattak az együttmüködó országok.

Az I. sz. problémakör a környezetvédelem társadalmi, gazdasági, jogi, földrajzi és pedagógiai tudományok területét öleli fel, zömében alapkutatás jelleggel. E kutatások során nemzetközi együttmüködésben közösen kutatunk olyan alapvető kérdéseket, mint a természethasznositás szocialista tervezési módszerének kidolgozása, a természeti eröforrások és a környezet állapotára vonatkozó gazdasági értékelés metodikája, a környezetvédelemre vonatkozó jogi szabályozás tudományos alapjai, a környezetvédelem oktatási problémái, a hulladékmentes, illetve kevés hulladékkal járó technológiák bevezetésének gazdasági, szervezési feltételei és a határon átterjedő levegőszenynyeződés jogi kérdései.

Ezek a kutatási témák a magyar környezetvédelmi politikának is alapvető gondjait jelentik.

A környezetvédelem terén kialakult együttmúködésre az utóbbi öt év során jellemzó volt, hogy a KGST-tagországok közös érdekének megfelelóen az I. problémakör társadalomtudományi jellegủ kutatásain belül jelentósen megnőtt a közgazdasági témák súlya. Az országonként sajátos konkrét tervezési-irányítási mechanizmusok lényegében hasonló kulcskérdéseket vetnek fel: a környezetvédelem hatékonyságának értelmezését, kritériumait és ennek alapján a környezetvédelmi tevékenység irányítási, tervezési rendszerének közgazdasági eszközeit, módjait lágazati problémáit éppen úgy. mint a területieket), továbbá a környezet és a környezeti tényezők közgazdasági értékelésének módszereit, valamint a környezeti károsodás közgazdasági értékelésének metodikáját. 